\title{
GENOTYPIC, PHENOTYPIC CORRELATION AND PATH COEFFICIENT IN MAIZE.
} II. YIELD AND YIELD COMPONENTS K. M. Wuhaib
Prof.
B. H. Hadi

Assist Prof.

\section{Crop Dept. - College of Agriculture-University of Baghdad}
Kareema522@yahoo.com
Wa.hassan69@yahoo.com
bhd.1970@yahoo.com

\section{ABSTRACT}

The experiment was carried out at the field of Field Crop - College of Agriculture-Univ. of Baghdad, during spring and fall seasons of 2013, under two levels of Nitrogen; 200 and $400 \mathrm{~kg} \mathrm{N.ha}{ }^{-1}$, by using Randomized Complete Block Design, with four replications. The objectives of the experiment were to estimate the genotypic, phenotypic and environmental correlations and path coefficient of yield and its components that correlated with yield to rely on them as selection criteria for high yield of maize. Results of statistical analysis showed that studied traits contributed with $99 \%$ and $85 \%$ of yield variance at spring and fall under $200 \mathrm{~kg} \mathrm{~N} \cdot \mathrm{ha}^{-1}$. respectively, and $99 \%$ and $93 \%$ of yield variance at spring and fall under $400 \mathrm{~kg} \mathrm{~N} . \mathrm{ha}^{-1}$ respectively. The trait number of grains plant ${ }^{-1}$ exhibited positive and highly significant genotypic and phenotypic correlation with yield, followed by other traits, while the grain weight correlated negative and highly significant correlation with yield, at spring under $200 \mathrm{~kg} \mathrm{~N} \cdot \mathrm{ha}^{-1}$. Traits e.g. number of grains row ${ }^{-1}$, number of grains Plant ${ }^{-1}$, weight of grain, and crop growth rate exhibited positive and highly significant correlation with yield. Under $400 \mathrm{~kg} \mathrm{N.ha-1}$. In both seasons, all traits had positive high significant phenotypic and genotypic correlation, except days to maturity was negative and high significant with yield. In spring and fall under $200 \mathrm{~kg} \mathrm{~N} . \mathrm{ha}^{-1}$. grains plant exhibited positive high value of direct effect in yield followed by grain weight . Crop growth rate exhibited positive direct effect in yield in fall season. Under $400 \mathrm{~kg} \mathrm{~N}^{-h^{-1}}$, in spring the highest direct effect was to grains plant $^{-1}$ followed by other traits except grain row ${ }^{-1}$ was negative, while in fall the highest direct effect were for grains plant ${ }^{-1}$, grain weight and crop growth rate. It can be concluded that these traits could be used as selection criteria for yield improvement in maize in breeding programs.

Key words: Maize, direct effect, phenotypic and genotypic correlation, path coefficient.

\begin{tabular}{|c|c|c|c|}
\hline وهيب وآخرون & & $2017 /$ & مجلة العلوم الزراعية العراقية - 885- \\
\hline & حاصل ومكوناته & ذأرة الصفراء و معامل & الارتباطات الوراثية \\
\hline & بنان حسن هادي & وجيهة عبد حسن & كريمة محمد وهيب \\
\hline & 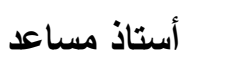 & مدرس & 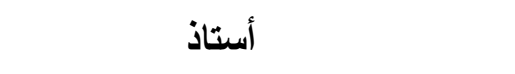 \\
\hline
\end{tabular}

bhd.1970@yahoo.com_Wa.hassan69@yahoo.com Kareema522@yahoo.com

تم تنفيذ تجريـة في حقل قسم المحاصيل الحقلية-كلية الزراعة-جامعة بغداد لموسمين ربيعي وخريفي 2013 تحت مستويين من النايتروجين 200

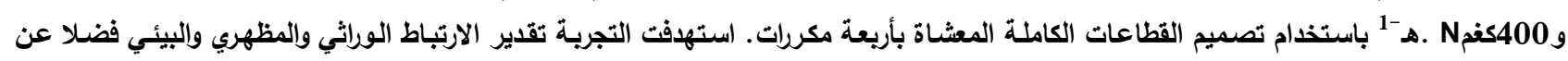
معامل المسار للحاصل ومكوناته المرتبطة به لاعتمادها معايير انتخاب للحاصل العالي للذرة الصفراء. حلت البيانات وتم تقدير المعالم الوراثية. أظهرت النتائج أن الصفات التي درست أسهمت نسبة 99\% و85\% من تغاير الحاصل في الموسم الربيعي والخريفي تحت مستوى النايتروجين 200كفم N . .

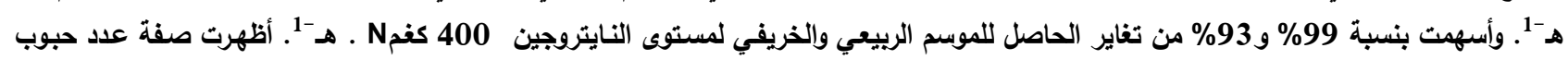

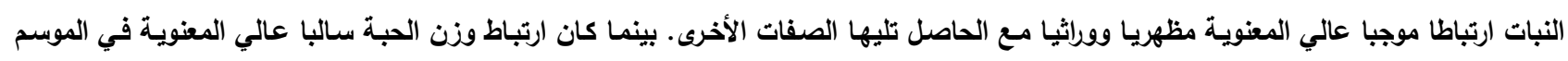

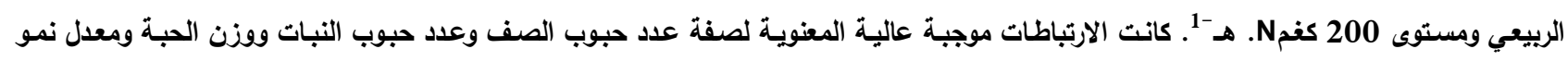

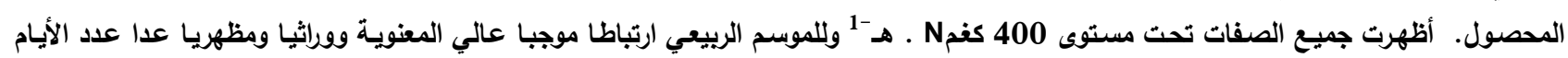

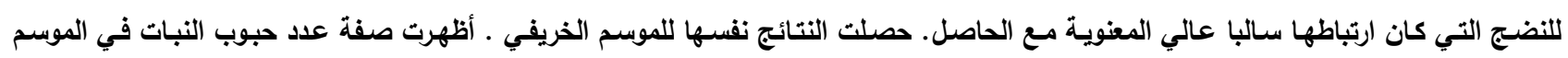

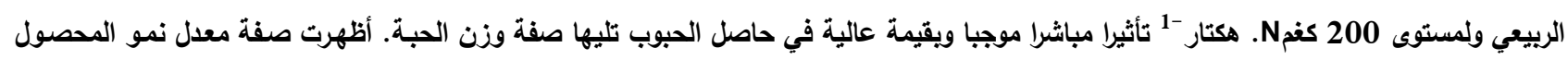

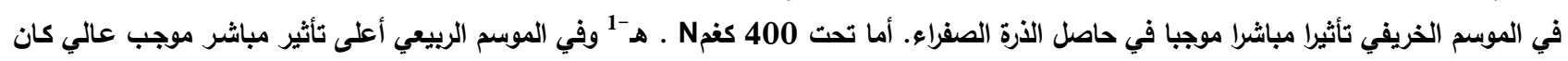

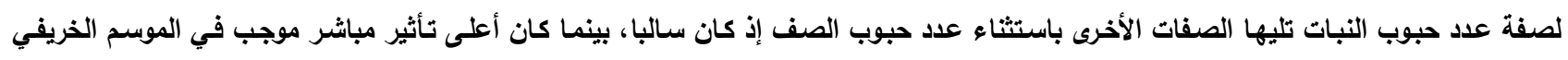

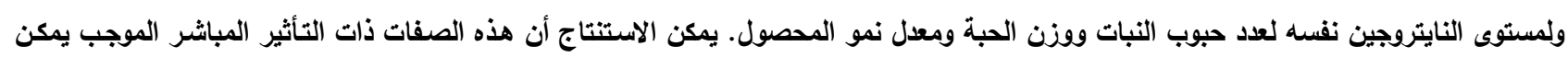
اعتبارها معايير انتخاب لتحسين الحاصل لمحصول الأرة الصفراء في برامج التربية. كلمات دالة: الذرة الصفراء، التأثير المباشر، الارتباط الوراثي والمظهري، معامل المسار. 


\section{INTRODUCTION}

Response to selection depends on many factors such as interrelationships of the traits. Plant breeders works with some yield components related to yield in the selection programs and it is very important to determine relative importance of such traits contributing to grain yield directly or indirectly. Path analysis parameters were used to determine the amount of direct and indirect effects of the variables on the dependent variable $(8,10,16)$. Correlation and path coefficient analysis could be used assist to determine certain traits to be used in the improvement of the complex traits such as grain yield (12). Since grain yield in maize is quantitative and poly genetic controlled, effective yield improvement and simultaneous improvement in yield components are imperative (6). Selection on the basis of grain yield alone is usually not very effective and efficient. However , selection based on its component could be more efficient and reliable (18). When there is positive association of major yield component traits, components breeding would be very effective, but when these traits are negatively associated, it would be difficult to exercise simultaneous selection for them in variety developing (19). The values of genotypic correlation among traits were greater than phenotypic values . The results obtained by Baktash and Wuhaib (4) showed that the values of genotypic correlation larger than the phenotypic, except for the number of grains row $^{-1}$. In the first and second seasons were positive, significant genotypic and phenotypic correlation between grain yield and number of grains row ${ }^{-1}$. Hadi and wuhaib (12) found that all genotypic correlations were higher than phenotypic, the highest values were 0.844 for grains ear $^{-1}$ for genotypic and 0.853 for number of grains row $^{-1}, 0.819$ for number of grains ear ${ }^{-1}$ for genotypic correlations. Bunder (5) reported that the high values of phenotypic correlation with yield were 0.959 for 300 grain weight and 0.898 for number of grain row $^{-1}$. Path analysis showed high positive direct effects of yield components on grain yield plant $^{-1}$. Ear grain weight had high positive direct effect on grain yield, but showed significant negative correlation with grain yield through large negative indirect effects of on other yield component (2). The results of several researchers showed possibility of grain yield improvement by using ear weight as selection criteria. Number of grain row $^{-1}$ and grain weight had positive effects on ear yield (20). Number of grains.row ${ }^{-1}$ exerted a maximum direct effect on grain yield $(1,3,9,11)$. Mohammadi et al. (17) found that 100 grain weight and total number of grains ear $^{-1}$ revealed highest direct effects on total grain weight, grains ear $^{-1}$ and number of grains.row $^{-1}$. The path coefficient analysis at phenotypic level revealed that trait, 100 grain weight exhibited the largest direct effect on grain yield per plant, followed by number of grains.row $^{-1}$. Days to maturity recorded negative direct effect on grain yield $(13,21)$. Grain yield was positively and significantly associated with number of grain ear ${ }^{-1}$, number of grain row $^{-1}$ and 1000 grain weight (7, 15,18). The objective of the experiment was to estimate phenotypic, genotypic and environment correlations and path coefficient to determine the best selection criteria to improve the grain yield and yield components of maize.

\section{MATERIAL AND METHODS}

The experiment was conduct at the field of the Dept. of Field Crop -Coll. of Agric.-Univ. of Baghdad. Seeds of synthetic cultivar Buhoth106 were planted during spring and fall season of 2013,in 17-3 for spring and in 18-7 for fall season. Plant spacing distance was $(70 \times 25 \mathrm{~cm})$. Two levels of nitrogen ( 200 and $400 \mathrm{~kg} \mathrm{~N} \cdot \mathrm{ha}^{-1}$ ) were used which added as three parts, the first part at seeding, the second at elongation stage (30 days after emergency) and the third at flowering stage ( 60 days after emergency). Randomized Complete Block Design used with four replications. At harvesting, 10 plants were taken to determine the yield and yield components and other traits to estimate the phenotypic, genotypic and environmental correlation for each traits and path coefficient for them using formula found by Singh and Chaudhary (22).

\section{RESULT AND DISCUSSION}

Genotypic, phenotypic and environmental correlation under $200 \mathrm{~kg} \mathrm{~N}$ level for the spring season: Table 1 and 2. illustrate the genotypic,phenotypic and environment correlation with grain yield and yield 


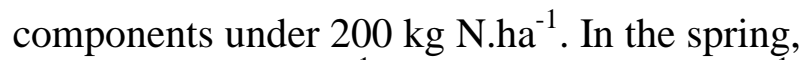
number of rows ear ${ }^{-1}$, number of grains row $^{-1}$, number of grains plant ${ }^{-1}$, days to maturity and crop growth rate exhibit positive significant genotypic and phenotypic correlation with yield, only grain weight exhibited negative and highly significant genetic and phenotypic with yield (-0.836 and -0.708$)$ respectively, as well as with other traits, while the rest traits correlated with each positive significant or highly significant genetic and phenotypic, the highest genotypic and phenotypic values were for grain plant $^{-1}(0.799$ and 0.692) respectively.

Genotypic, phenotypic and environmental correlation under $200 \mathrm{~kg} \mathrm{~N}$ level for the fall season: In fall season, the correlations were differed (Table 3,4). Number of grains row $^{-1}$, number of grains plant ${ }^{-1}$, grain weight and crop growth rate associated with yield positively and highly significant both genotypic and phenotypic $(0.902,0.922,0.531$ and 0.840$)$ respectively. Number of rows ear ${ }^{-1}$ and days to maturity were negative non- significant correlated with yield.

Genotypic, phenotypic and environmental correlation under $400 \mathrm{~kg} \mathrm{~N}$ level in the spring season: Under $400 \mathrm{~kg} \mathrm{~N} . \mathrm{ha}^{-1}$., in spring season, all traits exhibited positive and high significant association with yield of maize, (Table5,6). Negative and high significant genotypic and phenotypic correlations were existed between days to maturity against yield and other traits. While other traits correlated positive and high significant or significant genotypic and phenotypic with each other. Similar results were found by Wuhaib(20).

Genotypic, phenotypic and environmental correlation under $400 \mathrm{~kg} \mathrm{~N}$ level for the fall season: In fall season, the relationships among traits were different (Table7,8). All correlations between traits and yield and among them were positive and either significant or high significant, except days to maturity which had negative highly significant with yield and other traits. The highest values were for grains row ${ }^{-1} 0.999$, grains plant $^{-1}$ 0.929 and crop growth rate 0.829 . In general, the higher magnitude of genotypic correlation than their phenotypic in most of the traits means a strong genetic association exists for these traits and selection may be suitable to improve the yield of plant and use these traits as selection criteria in breeding program. The indices which were consisting of two, three and four traits at a time were more efficient than those based on individual traits. Negative correlations among the major crop plants especially under various types of environmental stress correlated with each other genotypic and phenotypic. Hadi and Wuhaib(12) found that selection of higher yield plant $^{-1}$ using grain number mention selection criterion gave higher grain yield under low and high nitrogen.

Table 1. Genotypic and phenotypic correlation between yield and other traits under $200 \mathrm{~kg} \mathrm{~N}$ level for the spring season 2013

\begin{tabular}{|c|c|c|c|c|c|c|c|}
\hline Traits * & RN/E & GN/R & TGN & GW & DTM & CGR & $\mathbf{Y}$ \\
\hline RN/E & 1.000 & 0.282 & $0.558^{* * *}$ & $-0.627^{* * *}$ & 0.288 & $0.347^{*}$ & $0.369^{*}$ \\
\hline GN/R & 0.255 & 1.000 & $0.776^{* * *}$ & $-0.794^{* * *}$ & $0.873^{* *}$ & $0.843^{* *}$ & $0.541^{* *}$ \\
\hline TGN & $0.473^{* *}$ & $0.654^{* *}$ & 1.000 & $-0.799^{* *}$ & $0.807^{* *}$ & $0.595^{* *}$ & $0.799^{* *}$ \\
\hline GW & $-0.479^{* *}$ & $-0.681^{* *}$ & $-0.693^{* *}$ & 1.000 & $-0.631^{* *}$ & $-0.695^{* *}$ & -0.836 ** \\
\hline DTM & 0.168 & $0.755^{* *}$ & $0.682^{* *}$ & $-0.561^{* *}$ & 1.000 & $0.805^{* *}$ & $0.476^{* *}$ \\
\hline CGR & 0.153 & $0.558^{* * *}$ & $0.370^{*}$ & $-0.487^{* *}$ & $0.633^{* * *}$ & 1.000 & $0.451^{* *}$ \\
\hline $\mathbf{Y}$ & $0.329^{*}$ & $0.472^{* *}$ & $0.692^{* *}$ & $-0.708^{* * *}$ & $0.354^{*}$ & 0.272 & 1.000 \\
\hline
\end{tabular}

Table 2. Environment correlation between yield and other traits under $200 \mathrm{~kg} \mathrm{~N}$ level for the spring season 2013

\begin{tabular}{|l|l|l|l|l|l|l|l|}
\hline Traits * & RN/E & GN/R & TGN & GW & DTM & CGR & Y \\
\hline RN/E & $\mathbf{1 . 0 0 0}$ & $\mathbf{0 . 1 6 7}$ & $\mathbf{0 . 1 3 1}$ & $\mathbf{0 . 1 7 8}$ & $\mathbf{0 . 2 1 7}$ & $\mathbf{0 . 1 7 0}$ & $\mathbf{0 . 1 9 2}$ \\
GN/R & & $\mathbf{1 . 0 0 0}$ & $\mathbf{- 0 . 0 5 6}$ & $\mathbf{0 . 0 0 6}$ & $\mathbf{0 . 2 6 2}$ & $\mathbf{0 . 0 2 2}$ & $\mathbf{0 . 1 2 5}$ \\
TGN & & & $\mathbf{1 . 0 0 0}$ & $\mathbf{0 . 1 6 4}$ & $\mathbf{0 . 0 5 1}$ & $\mathbf{- 0 . 1 3 7}$ & $\mathbf{0 . 0 1 4}$ \\
GW & & & & $\mathbf{1 . 0 0 0}$ & $\mathbf{- 0 . 2 0 7}$ & $\mathbf{- 0 . 0 5 8}$ & $\mathbf{0 . 1 3 8}$ \\
DTM & & & & & $\mathbf{1 . 0 0 0}$ & $\mathbf{0 . 3 6 9}$ & $\mathbf{- 0 . 1 8 6}$ \\
CGR & & & & & & $\mathbf{1 . 0 0 0}$ & $\mathbf{- 0 . 0 9 6}$ \\
Y & & & & & & & $\mathbf{1 . 0 0 0}$ \\
\hline
\end{tabular}

*RN: Rows number ear $^{-1}$;GN/R:Grain number row $^{-1}$; TGN: Total grain number; GW: Grain weight;DTM: Days to maturity ;CGR: Crop growth rate;Y:yield 
Table 3. Genotypic and phenotypic correlation between yield and other traits under $200 \mathrm{~kg}$ $\mathrm{N}$ level for the fall season 2013

\begin{tabular}{|c|c|c|c|c|c|c|c|}
\hline Traits * & RN/E & GN/R & TGN & GW & DTM & CGR & $Y$ \\
\hline RN/E & 1.000 & $-0.403^{*}$ & -0.258 & 0.185 & -0.269 & 0.126 & -0.279 \\
\hline GN/R & -0.358 & 1.000 & $0.885^{* * *}$ & $0.611^{* *}$ & -0.112 & $0.739^{* *}$ & $0.902^{* * *}$ \\
\hline TGN & -0.222 & $0.785^{* *}$ & 1.000 & $0.413^{*}$ & $-0.353^{*}$ & $0.738^{* *}$ & $0.922^{* * *}$ \\
\hline GW & 0.159 & $0.535^{* *}$ & $0.359^{*}$ & 1.000 & 0.159 & $0.589^{* * *}$ & $0.531^{* * *}$ \\
\hline DTM & -0.187 & -0.037 & -0.282 & 0.101 & 1.000 & $-0.495^{* * *}$ & -0.230 \\
\hline CGR & 0.076 & $0.679^{* * *}$ & $0.681^{* * *}$ & $0.564^{* *}$ & $-0.428^{* * *}$ & 1.000 & $0.840^{* * *}$ \\
\hline $\mathbf{Y}$ & -0.244 & $0.801^{* * *}$ & $0.832^{* * *}$ & $0.468^{* *}$ & -0.183 & $0.798^{* *}$ & 1.000 \\
\hline
\end{tabular}

Table 4. Environment correlation between yield and other traits under $200 \mathrm{~kg} \mathrm{~N}$ level for the fall season 2013

\begin{tabular}{|l|l|l|l|l|l|l|l|}
\hline Traits * & & GN/R & TGN & GW & DTM & CGR & Y \\
\hline RN/E & $\mathbf{1 . 0 0 0}$ & $\mathbf{- 0 . 2 0 9}$ & $\mathbf{- 0 . 0 8 9}$ & $\mathbf{0 . 0 6 1}$ & $\mathbf{- 0 . 0 1 1}$ & $\mathbf{- 0 . 3 5 5}$ & $\mathbf{- 0 . 1 1 9}$ \\
GN/R & & $\mathbf{1 . 0 0 0}$ & $\mathbf{0 . 1 0 8}$ & $\mathbf{- 0 . 1 1 0}$ & $\mathbf{0 . 2 0 5}$ & $\mathbf{0 . 0 6 5}$ & $\mathbf{0 . 1 4 4}$ \\
TGN & & & $\mathbf{1 . 0 0 0}$ & $\mathbf{- 0 . 1 9 7}$ & $\mathbf{- 0 . 0 6 6}$ & $\mathbf{- 0 . 1 5 4}$ & $\mathbf{0 . 1 3 7}$ \\
GW & & & & $\mathbf{1 . 0 0 0}$ & $\mathbf{- 0 . 1 5 2}$ & $\mathbf{0 . 0 2 2}$ & $\mathbf{- 0 . 1 4 9}$ \\
DTM & & & & & $\mathbf{1 . 0 0 0}$ & $\mathbf{- 0 . 3 6 8}$ & $\mathbf{- 0 . 0 4 4}$ \\
CGR & & & & & & $\mathbf{1 . 0 0 0}$ & $\mathbf{0 . 3 5 3}$ \\
Y & & & & & & & $\mathbf{1 . 0 0 0}$ \\
\hline
\end{tabular}

*RN: Rows number ear $^{-1}$;GN/R:Grain number row $^{-1}$;TGN: Total grain number; GW: Grain weight, DTM: Days to maturity ; CGR: Crop growth rate ;Y:yield

Table 5. The genotypic and phenotypic correlation between yield and other traits Under 400 $\mathrm{N}$ level in the spring season 2013

\begin{tabular}{|c|c|c|c|c|c|c|c|}
\hline Traits * & RN/E & GN/R & TGN & GW & DTM & CGR & $\mathbf{Y}$ \\
\hline RN/E & 1.000 & $0.517^{* * *}$ & $0.670^{* * * *}$ & $0.647^{* 3 *}$ & -0.906 & $0.787^{* * *}$ & $0.755^{* * *}$ \\
\hline GN/R & $0.366^{*}$ & 1.000 & $0.912^{* * *}$ & $0.431^{* * *}$ & -0.551 & 0.715 & 0.784 \\
\hline TGN & $0.482^{* *}$ & $0.845^{* *}$ & 1.000 & $0.356^{*}$ & $-0.621^{* *}$ & $\mathbf{0 . 7 8 3}^{* *}$ & $0.876 * *$ \\
\hline GW & $0.479^{* *}$ & $0.372^{*}$ & 0.279 & 1.000 & $-0.484^{* * *}$ & $0.768^{* * *}$ & $0.747^{* *}$ \\
\hline DTM & $-0.492^{* * *}$ & $-0.413^{*}$ & $-0.512^{* *}$ & $-0.382^{*}$ & 1.000 & $-0.831^{* *}$ & $-0.621^{* *}$ \\
\hline CGR & $0.508^{* * *}$ & $0.668^{* *}$ & $0.694^{* *}$ & $0.651^{* *}$ & $-0.734^{* *}$ & 1.000 & $0.932^{* *}$ \\
\hline $\mathbf{v}$ & $0.553^{* * *}$ & $0.696^{* *}$ & $0.761^{* * *}$ & $0.661^{* *}$ & $-0.505^{* *}$ & $\mathrm{o.833}^{* *}$ & 1.000 \\
\hline
\end{tabular}

Table 6. Environment correlation between yield and other traits under $400 \mathrm{~kg} N$ level for the spring season 2013

\begin{tabular}{|l|l|l|l|l|l|l|l|}
\hline Traits * & RN/E & GN/R & TGN & GW & DTM & CGR & Y \\
\hline RN/E & $\mathbf{1 . 0 0 0}$ & $\mathbf{0 . 0 0 2}$ & $\mathbf{0 . 0 5 1}$ & $\mathbf{0 . 1 1 1}$ & $\mathbf{0 . 3 3 5}$ & $\mathbf{- 0 . 3 2 4}$ & $\mathbf{0 . 0 7 1}$ \\
GN/R & & $\mathbf{1 . 0 0 0}$ & $\mathbf{- 0 . 4 1 8}$ & $\mathbf{0 . 0 0 4}$ & $\mathbf{0 . 2 1 0}$ & $\mathbf{0 . 2 7 6}$ & $\mathbf{0 . 0 5 5}$ \\
TGN & & & $\mathbf{1 . 0 0 0}$ & $\mathbf{- 0 . 1 6 7}$ & $\mathbf{- 0 . 0 5 5}$ & $\mathbf{0 . 0 0 7}$ & $\mathbf{- 0 . 0 0 7}$ \\
GW & & & & $\mathbf{1 . 0 0 0}$ & $\mathbf{0 . 0 4 3}$ & $\mathbf{- 0 . 2 4 4}$ & $\mathbf{0 . 0 9 4}$ \\
DTM & & & & & $\mathbf{1 . 0 0 0}$ & $\mathbf{- 0 . 2 8 3}$ & $\mathbf{0 . 0 3 2}$ \\
CGR & & & & & & $\mathbf{1 . 0 0 0}$ & $\mathbf{- 0 . 0 6 3}$ \\
Y & & & & & & & $\mathbf{1 . 0 0 0}$ \\
\hline
\end{tabular}

*RN: Rows number ear ${ }^{-1}$;GN/R:Grain number row $^{-1}$;TGN: Total grain number; GW: Grain weight;DTM: Days to maturity ;CGR: Crop growth rate ;Y:yield

Table 7. Genotypic and phenotypic correlation between yield and other traits under $400 \mathrm{~kg}$ $\mathrm{N}$ level for the fall season 2013

\begin{tabular}{|c|c|c|c|c|c|c|c|}
\hline Traits* & RN/E & GN/R & TGN & GW & DTM & CGR & $\mathbf{Y}$ \\
\hline RN/E & 1.000 & $0.348^{*}$ & 0.234 & 0.142 & $\begin{array}{c}-0.251 \\
\end{array}$ & 0.069 & 0.232 \\
\hline GN/R & 0.284 & 1.000 & $0.952^{* *}$ & $0.338^{*}$ & $-0.757^{* *}$ & $0.848^{* *}$ & $0.999^{* * *}$ \\
\hline TGN & 0.185 & 0.858 ** & 1.000 & 0.002 & $-0.565^{* *}$ & $0.675^{* *}$ & $0.929 * *$ \\
\hline GW & 0.091 & $0.328^{*}$ & -0.011 & 1.000 & $-0.554^{* *}$ & $0.663^{* *}$ & $0.349^{*}$ \\
\hline DTM & -0.202 & $-0.668^{* * *}$ & $-0.485^{* *}$ & -0.459 ** & 1.000 & $-0.791 *$ & -0.736 * \\
\hline CGR & 0.059 & $0.774^{* * *}$ & $0.620^{* *}$ & $0.610^{* * *}$ & $-0.742^{* *}$ & 1.000 & $0.829^{* * *}$ \\
\hline $\mathbf{V}$ & 0.186 & $0.836^{* *}$ & $0.836^{* *}$ & $0.326 *$ & $-0.572^{* *}$ & $0.735^{* * *}$ & 1.000 \\
\hline
\end{tabular}


Table 8. Environment correlation between yield and other traits under $400 \mathrm{~kg} \mathrm{~N}$ level for the fall season 2013.

\begin{tabular}{|l|l|l|l|l|l|l|l|}
\hline Traits * & RN/E & GN/R & TGN & GW & DTM & CGR & Y \\
\hline RN/E & $\mathbf{1 . 0 0 0}$ & $\mathbf{- 0 . 0 5 7}$ & $\mathbf{- 0 . 0 7 5}$ & $-\mathbf{0 . 1 5 6}$ & $\mathbf{0 . 0 4 4}$ & $\mathbf{- 0 . 0 0 0 4}$ & $\mathbf{0 . 0 4 0}$ \\
GN/R & & 1.000 & $\mathbf{- 0 . 0 2 8}$ & $\mathbf{0 . 2 4 4}$ & $\mathbf{0 . 1 3 3}$ & $\mathbf{- 0 . 1 8 8}$ & $\mathbf{- 0 . 0 9 8}$ \\
TGN & & & 1.000 & $-\mathbf{0 . 1 0 8}$ & $\mathbf{0 . 2 2 8}$ & $\mathbf{- 0 . 0 6 8}$ & $\mathbf{0 . 4 5 1}$ \\
GW & & & & $\mathbf{1 . 0 0 0}$ & $\mathbf{0 . 2 6 8}$ & $\mathbf{0 . 0 7 2}$ & $\mathbf{0 . 2 4 1}$ \\
DTM & & & & & 1.000 & $\mathbf{- 0 . 1 8 4}$ & $\mathbf{0 . 1 9 9}$ \\
CGR & & & & & & $\mathbf{1 . 0 0 0}$ & $\mathbf{0 . 3 0 3}$ \\
Y & & & & & & & 1.000 \\
\hline
\end{tabular}

*RN: Rows number ear ${ }^{-1}$; GNIR:Grain number row $^{-1}$; TGN: Total grain number; GW: Grain weight;DTM: Days to maturity ; CGR: Crop growth rate ;Y:yield

Path coefficient at level of $200 \mathrm{~kg} \mathbf{N}$ for the total effect was high positive value due to spring and fall seasons:

Path coefficient analysis has been useful to elucidate the direct and indirect relationships among grain yield and yield components and other traits. The results of path coefficient analysis under $200 \mathrm{~kg} \mathrm{~N} \cdot \mathrm{ha}^{-1}$ are presented in Table 9. In the spring the number of grains plant $^{-1}$ exhibited positive direct (1.252) and total effect $(0.799)$ on yield, followed by grain weight(0.513), this due to high positive indirect effect via days to maturity (1.037) followed by grain weight $(0.306)$ for number of grains, and days to maturity (0.902) and number of grains plant ${ }^{-1}$ for grain weight. In spite of negative direct effect of rows ear ${ }^{-1}$ (0.839 )and grains row ${ }^{-1}$ and crop growth rate ($0.326)$, the total effects of them positive (0.369and 0.541) due to positive indirect effect via grains plant ${ }^{-1}(0.699)$, grain weight $(0.178)$ and days to maturity $(0.813)$ for rows ear ${ }^{-1}$ and grains plant ${ }^{-1}(0.971,0.433)$ for grain weight and 1.030 for days to maturity for grain row $^{-1}$; grains plant ${ }^{-1}(1.009)$, grain weight $(0.414)$ and days to maturity $(0.818)$ for crop growth rate. In fall season, grains plant ${ }^{-1}$ and crop growth rate showed positive high value of direct (0.773and 0.740) and total effect $(0.922$ and 0.840 ) due to high positive indirect effect of crop growth rate $(0.546)$ for grains plant ${ }^{-1}$ and (0.571) of grains plant ${ }^{-1}$ for crop growth rate . In spite of the negative direct effect of grains row $^{-1}$, the total effect was positive and have high value due to high positive indirect effect of grains plant ${ }^{-1}(0.683)$ and crop growth rate (0.547) followed by rows $\operatorname{ear}^{-1}(0.124)$, then grain weight (049). In contrast the direct effect of days to maturity was positive $(0.259)$, the total effect was negative $(-0.230)$ due to high negative indirect effect via crop growth rate ($0.366)$ followed by grain plant ${ }^{-1}(-0.275)$. The direct effect of grain weight was a little but the positive indirect effect via grains plant ${ }^{-1}(0.319)$ , crop growth rate $(0.436)$ and days to maturity (0.259).

Path coefficient at level of $400 \mathrm{~kg} \mathrm{~N}$ for the spring and fall seasons: In spring season, under $400 \mathrm{~kg} \mathrm{~N} \cdot \mathrm{ha}^{-1}$ the result revealed that all traits have positive direct effect except grains row $^{-1}$ which was negative(Table10), and all traits exhibited positive total effect except days to maturity which was negative. The highest and positive direct effect was for grains plant ${ }^{-1}$ (0.950) followed by crop growth rate(0.445) then grain weight $(0.368)$ and days to maturity $(0.350)$. In fall season, the highest and positive direct effect(2.020) accompanied with high total effect $(0.929)$ was for grains plant $^{-1}$. Crop growth rate showed a high positive direct and total effect $(0.723$ and 0.829 ) due to a high positive indirect effect via grains plant $^{-1}(1.365)$ and grain weight $(0.649)$ followed by days to maturity $(0.158)$. Grain weight showed a high positive direct effect (0.980), but the total effect was positive and less than the direct effect $(0.350)$ due to the negative indirect effect via crop growth rate($0.479)$ and grains row $^{-1}(-0.244)$. Mohmmadi et al.(14) reported that 100 grain weight and total number of grains ear ${ }^{-1}$ showed highest direct effects on total grain weight, grains ear ${ }^{-1}$ and number of grains row ${ }^{-1}$. Days to maturity showed negative direct effect $(-0.200)$, and high negative total effect $(-0.736)$ because high and negative indirect effect via grains plant $^{-1}(-1.143)$ and grain weight $(-0.543)$. In spite of the negative and high value $(-0.721)$ of direct effect for grains row $^{-1}$, the total effect was positive and high (1.028), this could be due to positive and high indirect effect through grains plant ${ }^{-1}$ (1.924) then grain weight (0.332). From these results it can be concluded that the percentage of the contribution of these 
traits in variance of yield were $99 \%$ and $85 \%$ for two seasons under $200 \mathrm{~kg} \mathrm{~N} \cdot \mathrm{ha}^{-1}$, while their contribution for two seasons under 400 $\mathrm{kg} \mathrm{N} . \mathrm{ha}^{-1}$. were $99 \%$ and $93 \%$ respectively. Grains plant $^{-1}$, grain weight and crop growth

Table 9. Path coefficient of some maize traits with yield at level of $200 \mathrm{~kg}$ nitrogen for two seasons 2013.

\begin{tabular}{|c|c|c|c|c|c|c|c|}
\hline \multicolumn{8}{|c|}{ Spring season } \\
\hline Traits* & $\mathbf{R N} / \mathbf{E}$ & GN/R & TGN & GW & DTM & CGR & $\begin{array}{l}\text { Total } \\
\text { effects }\end{array}$ \\
\hline RN/E & -0.839 & -0.386 & 0.699 & 0.178 & 0.813 & -0.094 & 0.369 \\
\hline GN/R & -0.237 & -1.371 & 0.971 & 0.433 & 1.030 & -0.285 & 0.541 \\
\hline TGN & -0.468 & -1.063 & 1.252 & 0.306 & 1.037 & -0.263 & 0.799 \\
\hline GW & -0.291 & -1.156 & 0.744 & 0.513 & 0.902 & -0.263 & 0.452 \\
\hline DTM & 0.526 & 1.088 & 1.000 & -0.357 & -1.298 & 0.206 & -0.835 \\
\hline CGR & -0.242 & -1.197 & 1.009 & 0.414 & 0.818 & -0.326 & 0.476 \\
\hline $\begin{array}{l}\text { R } \\
\text { Effect }\end{array}$ & 0.012 & & & & & & \\
\hline \multicolumn{8}{|c|}{ Fall season } \\
\hline Traits * & RN/E & GN/R & TGN & GW & DTM & CGR & $\begin{array}{l}\text { Total } \\
\text { effects }\end{array}$ \\
\hline RN/E & -0.309 & 0.191 & 0.199 & 0.015 & -0.069 & 0.093 & -0.279 \\
\hline GN/R & 0.124 & -0.475 & 0.683 & 0.049 & -0.029 & 0.547 & 0.902 \\
\hline TGN & 0.080 & -0.419 & 0.773 & 0.033 & -0.091 & 0.546 & 0.922 \\
\hline GW & -0.057 & -0.289 & 0.319 & 0.082 & 0.041 & 0.436 & 0.531 \\
\hline DTM & 0.083 & 0.053 & -0.275 & 0.013 & 0.259 & -0.366 & -0.230 \\
\hline CGR & -0.039 & -0.351 & 0.571 & 0.048 & -0.128 & 0.740 & 0.840 \\
\hline R Effect & 0.153 & & & & & & \\
\hline
\end{tabular}

* RN: Rows number ear $^{-1}$;GNIR:Grain number per row; TGN: Total grain number; GW: Grain weight; DTM: Days to maturity ;CGR: Crop growth rate; Y: yield

Table10. Path coefficient of some maize traits with yield at level of $400 \mathrm{~kg}$ nitrogen for two seasons 2013

\begin{tabular}{|l|c|c|c|c|c|c|c|}
\hline \multicolumn{10}{|c|}{ Spring season } \\
\hline Traits & RN/E & GN/R & TGN & GW & DTM & CGR & $\begin{array}{l}\text { Total } \\
\text { effects }\end{array}$ \\
\hline RN/E & $\mathbf{0 . 0 5 7}$ & $\mathbf{- 0 . 2 0 4}$ & $\mathbf{0 . 6 2 4}$ & $\mathbf{0 . 2 3 6}$ & $\mathbf{- 0 . 3 1 0}$ & $\mathbf{0 . 3 4 3}$ & $\mathbf{0 . 7 4 5}$ \\
GN/R & $\mathbf{0 . 0 2 8}$ & $\mathbf{- 0 . 4 0 8}$ & $\mathbf{0 . 8 6 8}$ & $\mathbf{0 . 1 5 1}$ & $\mathbf{- 0 . 1 8 5}$ & $\mathbf{0 . 3 1 6}$ & $\mathbf{0 . 7 7 0}$ \\
TGN & $\mathbf{0 . 0 3 7}$ & $\mathbf{- 0 . 3 7 3}$ & $\mathbf{0 . 9 5 0}$ & $\mathbf{0 . 1 2 9}$ & $\mathbf{- 0 . 2 1 7}$ & $\mathbf{0 . 3 4 8}$ & $\mathbf{0 . 8 7 6}$ \\
GW & $\mathbf{0 . 0 3 6}$ & $\mathbf{- 0 . 1 6 7}$ & $\mathbf{0 . 3 3 4}$ & $\mathbf{0 . 3 6 8}$ & $\mathbf{- 0 . 1 6 8}$ & $\mathbf{0 . 3 3 9}$ & $\mathbf{0 . 7 4 2}$ \\
DTM & $\mathbf{- 0 . 0 5 0}$ & $\mathbf{0 . 2 1 6}$ & $\mathbf{- 0 . 5 9 0}$ & $\mathbf{- 0 . 1 7 7}$ & $\mathbf{0 . 3 5 0}$ & $\mathbf{- 0 . 3 6 9}$ & $\mathbf{- 0 . 6 2 1}$ \\
CGR & $\mathbf{0 . 0 4 4}$ & $\mathbf{- 0 . 2 9 0}$ & $\mathbf{0 . 7 4 4}$ & $\mathbf{0 . 2 8 0}$ & $\mathbf{- 0 . 2 9 0}$ & $\mathbf{0 . 4 4 5}$ & $\mathbf{0 . 9 3 2}$ \\
R Effect & $\mathbf{0 . 0 1 2}$ & & & & & & \\
\hline
\end{tabular}

RN: Rows number ear $^{-1}$;GN/R:Grain number row $^{-1}$;TGN: Total grain number; GW: Grain weight;DTM: Days to maturity ;CGR: Crop growth rate; $Y$ : yield

\section{REFERENCES}

1. Alvi, M. B.,M. Rafique, M. S. Tariq. A. Hussaain, T. Mohmood, and M. Sarwar. 2003. Character association and path coefficient analysis of grain yield and yield components of maize (Zea mays L.) . Pakistan J. of Biological Sci. 6(2): 136-138.

2. Amini, Z., K. Mahmood, and H. Sadallah. 2013. Correlation and path coefficient analysis of seed yield related traits in maize . Intl. J. Agric. Crop Sci. 5(19): 2217-2220.

3. Annapurna, D. H. A. Khan, S. Mohammad.1998.Genotypic-phenotypic

correlation and path coefficient analysis between seed yield and other associated character in tall genotypes of maize. Crop Res. Hisar 16: 205-209.

4. Baktash, F.Y. and K.M. Wuhaib. 2003. Genotypic and phenotypic variances and correlations in several maize characters. The Iraqi J. of Agric. Sci. 34(2): 91-100.

5.Bunder, S.2010. Estimation of variance, genotypic and phenotypic correlations for some traits of maize under nitrogen abundance. The Iraqi J. of Agric. Sci. 47(4): 933-938.

6. Bello, O. B., G. Olaoy. 2009.Combining ability for maize grain yield and other agronomic characters in atypical southern 
guinea savanna ecology of Nigeria. Afr. J. Biotech. 8(11): 2518-2522.

7. Bello, O. B., S. Y. Abdulmaliq, M. S. Afolabi, and S. A. Ige . 2010. Correlation and path coefficient analysis of yield and agronomic characters among open pollinated maize varieties and their F1 hybrids in a diallel cross. African J. of Biotech . 9(18) : 26332639.

8.Bidgoli, A. M., G. A. Akbari, M.J. Mirhadi, E. Zand and S. Soufizadeh. 2006. Path analysis of the relationships seed yield and some morphological and phonological traits in safflower (Carthamus tinctorius L.). Euphytica 148: 261-268.

9. Devi, I.S., S. Muhammad and S. Muhammad. 2001. Character association and path coefficient analysis of grain yield and yield components in double crosses of maize. Crop Res. Hisar 21: 355-359.

10. Farshadfar, E., B. Galiba, and J. K. Sutka .1993. Some aspects of the genetic analysis of drought tolerance in wheat . Cereal. Res. Commun. 21:323-330.

11. Geetha, K. and N.Sayavaman.2000. Path analysis in maize (Zea mays L.) . Agric. Sci. Digest. 20:60-61.

12.Hadi, B.H. and K.M. Wuhaib. 2010. Heritability and genetic gain in maize. AlAnbar J. Sci. 8(1): 96-107.

13.Joshi, B. K. 2005. Correlation, regression and path coefficient analysis for some yield components in common and Tartary buck wheat in Nepal. Fagopyrum 22: 77-82. 14.Kumar, P. G., Y. Prashanth, V. N. Reddy, S. S. Kumar, and P. V. Rao. 2014. Characters association and path coefficient analysis in maize (Zea mays L.) International J. OF Applied Biology and Pharmaceutical Technology 5: 257-260.

15.Kumar, M.V. N. and S.S. Kumar .2000. Studies on character association and path coefficient for grain yield and oil content in maize (Zea mays L.). Ann. Agric. Res. 21: 7378.

16. Li, C.C. 1956. The concept of path coefficient and it impact on population genetics. Biometrics 12:190-210. 17.Mohammadi, S. A., B. M. Prasanna, V. N. Sing .2003. Sequential path model for determining interrelationship among grain yield and related characters in maize . Crop Sci. 43: 1690-1697.

18.Muhammad, B.A., R. Muhammad. S. T. Muhammad, H. Amer, M. Tariq and S. A. Muhammad .2003. character association and path coefficient analysis of grain yield and yield components in maize . Pak. J. Biological Sci. 6(2): 136-138.

19.Nemati, A., M. Sedghi, R. S. Sharifi, and M. N. Seiedi. 2009. Investigation of correlation between traits and path analysis of corn (Zea mays L.) . Hort. Acrobats. Clue J. 37(1) : 194-198.

20.Rashidi, N., A. R. Golparvar, M. R. Naderigd and H. Darkhad. 2013. Evaluation of attributes association and path coefficients for ear yield in maize hybrids (Zea mays L.) International J. of Farming and Allied Sci. 2(22): 1033-1036.

21.Selvaraj, C. L. and Nagarajan. 2011. Interrelationship and path coefficient studies for qualitative traits, grain yield and other yield attributes among maize (Zea mays L.) . Int. J. Plant Breed. Genet. 5(3): 209-223.

22.Singh, P. K., and S. D. Chaudhary. 1985. Biometrical methods in quantitative genetics analysis. Khalyni New Delhi, India, PP. 318. 23. Wuhaib, K. M. 200. Evaluation of Maize Genotypes Responses To Different Levels of Nitrogen Fertilizer and Plant Populations and Path Coefficient Analysis. Ph.D. Dissertation, Field Crops. Dept. College of Agric. Baghdad, Iraq, pp:137. 